\title{
Makna Pengalihan Hak Kepemilikan Benda Objek Jaminan Fidusia Atas Dasar Kepercayaan ${ }^{1}$
}

\author{
Rachmadi Usman \\ Fakultas Hukum Universitas Lambung Mangkurat Banjarmasin \\ Kalimantan Selatan Indonesia \\ JIn. Brigjen H. Hassan Basry, Banjarmasin Kalimantan Selatan Indonesia \\ rachmadi.usman@ulm.ac.id
}

Received: 29 Juli 2020; Accepted: 19 Januari 2021; Published: 16 Maret 2021

DOI: 10.20885/iustum.vol28.iss1.art7

\begin{abstract}
The concept of fiduciary in legislation is "the transfer of ownership rights to an object on the basis of belief", while jurisprudence defines it as "the transfer of property rights based on trust". However, the object whose ownership rights have been transferred remains in the hands of the fiduciary. This fiduciary concept contains ambiguity, because in its imposition it is not clear how the transfer of property rights to the object of the fiduciary guarantee. The juridical and actual submission of movable objects generally occurs at the same time. The meaning of the transfer of ownership rights to objects of fiduciary security on the basis of this belief needs to be examined. This is a normative legal research using a statutory and historical approach. The results of the study conclude that the real and juridical submission of fiduciary security does not occur at the same time. The transfer of ownership rights to the object of fiduciary security is carried out as collateral for debt repayment, meaning false delivery, not really in the sense of the transfer of real ownership rights. The real delivery only occurs when the fiduciary is deemed in default, on the other hand the object of the fiduciary guarantee will be returned if the fiduciary is not in default. This transfer of ownership rights to the object of fiduciary security is intended to give the fiduciary the authority to act to sell the object of fiduciary security as well as to give preference to other creditors.
\end{abstract}

Key Words: Fiduciary duty; meaning; transfer of ownership

Abstrak

Konsep fidusia dalam perundang-undangan adalah "pengalihan hak kepemilikan suatu benda atas dasar kepercayaan", sedangkan yurisprudensi mengartikan "penyerahan hak milik atas dasar kepercayaan". Namun benda yang dialihkan hak kepemilikannya itu secara nyata tetap dikuasai pemberi fidusia. Konsep fidusia ini mengandung ambiguitas, sebab dalam pembebanannya tidak jelas cara penyerahan hak milik benda objek jaminan fidusianya. Penyerahan yuridis dan nyata kebendaan bergerak umumnya terjadi pada saat bersamaan. Makna pengalihan hak kepemilihan benda objek jaminan fidusia atas dasar kepercayaaan ini perlu diteliti. Penelitian ini merupakan penelitian hukum normatif menggunakan pendekatan perundang-undangan dan historis. Hasil penelitian menyimpulkan bahwa penyerahan yuridis dan nyata dalam pembebanan jaminan fidusia tidak terjadi pada saat bersamaan. Pengalihan hak kepemilikan benda objek jaminan fidusia dilakukan untuk penjaminan sebagai agunan pelunasan utang, bermakna penyerahan semu, bukan benar-benar dalam pengertian penyerahan hak milik sesungguhnya. Penyerahan nyata baru terjadi saat pemberi fidusia dianggap wanprestasi, sebaliknya benda objek jaminan fidusia akan dikembalikan jika pemberi fidusia tidak wanprestasi. Pengalihan hak kepemilikan benda objek jaminan fidusia ini dimaksudkan untuk memberikan kewenangan bertindak kepada penerima fidusia menjual benda objek jaminan fidusia sekaligus memberikan hak preferensi terhadap kreditor lainnya.

Kata-kata Kunci: Makna; pengalihan hak kepemilikan; jaminan fidusia

1 Hasil penelitian mandiri yang didadani oleh Fakultas Hukum Universitas Lambung Mangkurat Tahun Anggaran 2019 


\section{Pendahuluan}

Lembaga jaminan fidusia apabila dibandingkan dengan lembaga gadai dan hipotik, pada mulanya merupakan suatu bentuk jaminan yang lahir dari yurisprudensi. Kemudian untuk menampung kebutuhan masyarakat mengenai pengaturan jaminan fidusia dan agar lebih menjamin kepastian hukum bagi pihak yang berkepentingan, diadakan ketentuan yang lebih lengkap mengenai jaminan fidusia tersebut dengan dibentuknya Undang-Undang Nomor 42 Tahun 1999 tentang Jaminan Fidusia (Lembaran Negara Republik Indonesia Tahun 1999 Nomor 168, Tambahan Lembaran Negara Republik Indonesia Nomor 3889; untuk selanjutnya disebut UU No. 42/1999).

UU No. 42/1999 ini merupakan respon pemerintah terhadap kebutuhan masyarakat terhadap berbagai macam lembaga jaminan kebendaan, karena bentuk-bentuk perjanjian pinjam meminjam uang atau perjanjian kredit dengan jaminan kebendaan yang telah ada seperti hak tanggungan, gadai dan hipotik dianggap belum mengakomodasi kebutuhan masyarakat terhadap lembaga jaminan kebendaan. Selain itu, dengan diadakannya UU No. 42/1999 tersebut, akan memberikan status yang jelas lembaga jaminan fidusia, yang selama ini dikonstruksikan dalam berbagai bentuk seperti "Jual Beli dengan Hak Membeli Kembali", “Jual Beli Semu”, “Gadai Diam-diam”, dan "Perjanjian Penyerahan Hak Milik atas Dasar Kepercayaan", juga untuk memberikan kepastian hukum. ${ }^{2}$ Artinya pengaturan jaminan fidusia melalui yurisprudensi tidak menjamin kepastian hukum, karenanya perlu diatur dalam peraturan perundang-undangan secara lengkap dan komprehensif.

Beda dengan gadai yang objek benda jaminannya harus dikuasai oleh kreditor, hal mana sesuai dengan asas inbezitstelling, ${ }^{3}$ sementara itu tidak demikian dengan lembaga jaminan fidusia, penguasaan objek benda jaminannya tidak berada di tangan kreditor, melainkan ada di tangan debitor. Lembaga jaminan fidusia memungkinkan kepada para pemberi fidusia untuk menguasai benda yang

\footnotetext{
${ }^{2}$ Nurfaidah Said, Prinsip Penyerahan Objek Jaminan Atas Dasar Kepercayaan dalam Perjanjian Fidusia. Ringkasan, Disertasi, Program Doktor Program Pascasarjana Universitas Airlangga, Surabaya, 2008, hlm. 3.

${ }^{3}$ Fidusia merupakan salah satu lembaga jaminan yang didambakan oleh para pelaku usaha saat ini, atas dasar karakter penguasaan benda yang terlepas dari asas inbezitstelling, demikian menjadi serupa dengan karakter penguasaan benda pada jaminan Hipotek. Lihat Fani Martiawan Kumara Putra, "Karakteristik Pembebanan Jaminan Fidusia pada Benda Persediaan dan Penyelesaian Sengketa Saat Debitor Wanprestasi”, Jurnal Perspektif, Volume XXI, Nomor 1, Tahun 2016, Edisi Januari, hlm. 46.
} 
dijaminkan, untuk melakukan kegiatan usaha yang dibiayai dari pinjaman dengan menggunakan jaminan fidusia. Objek benda yang dapat dibebani dengan jaminan fidusia juga diperluas tidak hanya benda bergerak berwujud berupa peralatan, termasuk juga kekayaan benda bergerak tak berwujud maupun benda tak bergerak lainnya yang tidak menjadi objek hipotik dan hak tanggungan.

Istilah fidusia adalah upaya pemendekan dari kalimat "Fiduciaire Eigendoms-overdracht" (FEO) sebagai suatu konsep. ${ }^{4}$ Jika merujuk Pasal 1 angka 1 UU No. 42/1999, maka fidusia merupakan bentuk peralihan hak kepemilikan atas suatu benda objek jaminan fidusia. Menurut UU No. 42/1999, fidusia dikonsepkan sebagai "pengalihan hak kepemilikan suatu benda atas dasar kepercayaan", sementara yurisprudensi mengonsepkan fidusia sebagai "penyerahan hak milik atas dasar kepercayaan".

Hal di atas mengandung arti bahwa dalam jaminan fidusia itu telah terjadi pengalihan hak kepemilikan benda jaminan melalui penyerahan hak milik atas dasar kepercayaan. Benda yang hak kepemilikannya dialihkan tersebut tetap dikuasai oleh debitor pemberi fidusia, sementara itu hak kepemilikannya tetap berada di tangan kreditor penerima fidusia. Diketahui dari awal, kalau tujuan jaminan fidusia itu adalah menjamin pelunasan utang tertentu, bukan dalam rangka mengalihkan kepemilikan atas benda yang dibebani dengan jaminan fidusia. Dalam praktiknya, yang diserahkan itu "bukti kepemilikan" atas benda yang dibebani dengan jaminan fidusia.

Konsep fidusia dalam Pasal 1 angka 1 UU No. 42/1999 mengandung ambiguitas, di satu sisi dikatakan telah terjadi "pengalihan hak kepemilikan" atas benda yang dibebani dengan jaminan fidusia, tetapi di sisi lainnya dikatakan bahwa "benda yang dialihkan" tersebut tetap berada dalam "penguasaan pemilik bendanya". Apalagi kalau hal ini dikaitkan dengan konsep penyerahan hak milik menurut sistem hukum perdata berdasarkan Burgerlijk Wetboek (Staatsblad Tahun 1847 Nomor 23; untuk selanjutnya disebut BW), yang menghendaki tidak hanya ada penyerahan yuridis (juridische levering), tetapi juga ada penyerahan secara nyata (feitelijke levering). Hal ini agar terjadi pengalihan hak kepemilikan atas 96.

${ }^{4}$ Moch. Isnaeni, Noktah Ambigu Norma Lembaga Jaminan Fidusia, Revka Petra Media, Surabaya, 2017, hlm. 
benda secara sempurna, dikarenakan penyerahan yuridis dan penyerahan nyata pada benda bergerak umumnya terjadi disaat yang bersamaan. Pembebanan jaminan fidusia menjadi tidak jelas, apakah benar-benar terjadi pengalihan hak kepemilikan atas benda yang dibebani jaminan fidusia secara sempurna, sehingga kreditor penerima fidusia menjadi pemilik benda yang dibebani dengan jaminan fidusia itu ataukah tidak.

Menurut sistem hukum perdata, selain harus ada penyerahan nyata, sahnya suatu penyerahan kebendaan dalam rangka pengalihan hak kepemilikan atas benda tersebut, dipersyaratkan harus ada titel (alas hak). Hal ini ditegaskan dalam Pasal 584 BW, antara lain bunyi frasanya menyatakan: "Hak milik atas sesuatu kebendaan tak dapat diperoleh dengan cara lain, melainkan dengan "...penyerahan berdasar atas suatu peristiwa perdata untuk memindahkan hak milik". Berdasarkan Pasal 584 BW ini, maka pengalihan atau memindahkan hak milik atas suatu benda itu harus ada hubungan hukum dasarnya, yang merupakan "suatu peristiwa perdata", seperti jual beli, tukar menukar, atau penghibahan. Bila dibandingkan, dalam pembebanan fidusia, peristiwa perdatanya tidak jelas, tetapi hak kepemilikan atas suatu benda objek jaminan fidusia dikatakan telah beralih dari debitor pemberi fidusia kepada kreditor penerima.

Sesungguhnya Pasal 17 UU No. 42/1999 beserta dengan penjelasannya juga telah melarang pemberi fidusia melakukan fidusia ulang terhadap benda yang menjadi objek jaminan fidusia yang sudah terdaftar. Hal itu tidak memungkinkan atas benda yang menjadi objek jaminan fidusia, dikarenakan hak kepemilikan atas benda tersebut telah beralih kepada penerima fidusia. Dalam rangka pelaksanaan eksekusi jaminan fidusia, ketika penerima fidusia hendak mengambil atau menarik benda yang menjadi objek jaminan fidusia adakalanya dituduh melakukan tindak pidana perampasan atau perbuatan melanggar hukum.

Benda yang menjadi objek jaminan fidusia adakalanya juga ikut dirampas oleh negara melalui pengadilan, misalnya dalam Putusan Mahkamah Agung Nomor 1046 K/Pdt/2015. Hal ini berarti, hakikat pengalihan hak kepemilikan benda objek jaminan fidusia tidak memberikan dan melindungi kepastian hak preferensi dari penerima fidusia. Oleh karena itu, perlu dipertanyakan hakikat fidusia dalam jaminan fidusia dan esensialitas pengalihan hak kepemilikan benda 
objek jaminan atas dasar kepercayaan sebagai agunan pelunasan hutang dalam pembebanan jaminan fidusia tersebut.

\section{Rumusan Masalah}

Berdasarkan uraian latar belakang di atas, masalah hukum yang dirumuskan dalam penelitian ini adalah, pertama, bagaimana hakikat fidusia dalam jaminan fidusia? Kedua, bagaimana esensialitas pengalihan hak kepemilikan benda objek jaminan atas dasar kepercayaan sebagai agunan pelunasan hutang dalam pembebanan jaminan fidusia?

\section{Tujuan Penelitian}

Penelitian ini bertujuan untuk mengkaji dan menganalisis hakikat fidusia dalam jaminan fidusia dan esensialitas pengalihan hak kepemilikan benda objek jaminan atas dasar kepercayaan sebagai agunan pelunasan hutang dalam pembebanan jaminan fidusia.

\section{Metode Penelitian}

Metode penelitian yang digunakan dalam penelitian ini adalah metode penelitian hukum normatif dengan cara meneliti norma hukum yang berlaku. Pendekatan dalam penelitian hukum normatif ini adalah pendekatan perundangundangan (statute approach), pendekatan konseptual (conceptual approach), dan pendekatan sejarah (historical approach). Teknik pengumpulan bahan hukum yang digunakan adalah teknik kepustakaan (library research), yakni dengan meneliti berbagai perundang-undangan, pandangan-pandangan ahli hukum yang dikembangkan dalam doktrin hukum dan sejarah perkembangan hukum jaminan fidusia. Sifat pemaparan hasil dan pembahasan isu hukum dalam penelitian ini melalui metode analisis teks (content analysis) dan dianalisis secara preskriptif berdasarkan logika dan argumentasi hukum. 


\section{Hasil Penelitian dan Pembahasan}

\section{Hakikat Fidusia dalam Jaminan Fidusia}

Konsep dasar fidusia adalah kepercayaan sesuai dengan asal kata fidusia atau fides yang berarti kepercayaan. ${ }^{5}$ Asal kata fidusia dari bahasa Latin, yaitu "fiducia", kata dasar "fido", artinya saya mempercayai seseorang atau sesuatu, sedangkan istilah "fiducia" (kata benda), artinya kepercayaan terhadap seseorang atau sesuatu, pengharapan yang besar. "Fiducia" dimaksudkan peristiwa seorang debitur menyerahkan suatu benda kepada kreditornya dengan mengadakan jual pura-pura, dengan maksud menerima benda itu kembali dari kreditor tersebut setelah hutangnya dibayar.6 Sebelum lahirnya UU No. 42/1999, fidusia sering disebut sebagai jaminan hak milik secara kepercayaan. ${ }^{7}$

Fidusia dalam bahasa Indonesia disebut dengan istilah "penyerahan hak milik secara kepercayaan". 8 Istilah lengkapnya dalam terminologi Belanda adalah "fiduciare eigendom overdract", sedangkan dalam bahasa Inggris lengkapnya disebut "fiduciary transfer of ownership".9 Pasal 1 angka 1 UU No. 42/1999 menentukan batasan pengertian fidusia, yaitu: "pengalihan hak kepemilikan suatu benda atas dasar kepercayaan dengan ketentuan bahwa benda yang hak kepemilikannya dialihkan tersebut tetap dalam penguasaan pemilik benda".

Sementara itu istilah "fiducia" yang merupakan kata benda diartikan kepercayaan terhadap seseorang atau sesuatu, pengharapan yang besar. ${ }^{10}$ Sementara itu, dalam hukum Romawi istilah fidusia ini mengandung dua pengertian sebagai kata benda dan kata sifat. Sebagai kata benda, istilah fidusia memiliki arti seseorang yang diberikan amanah untuk mengurus kepentingan pihak ketiga dengan itikad baik, penuh ketelitian, bersikap hati-hati, dan berterus terang. Orang yang diberi kepercayaan, dibebani kewajiban melakukan perbuatan untuk kemanfaatan orang

\footnotetext{
${ }^{5}$ Memet Achirius Sjafar, "Perampasan Obyek Fidusia dan Akibat Hukumnya", Jurnal Notaire, Volume 2 Nomor 3, Oktober 2019, hlm. 374.

${ }^{6}$ Marulak Pardede (Ketua Tim), Laporan Akbir Penelitian Hukum Laporan Akbir Penelitian Hukum Tentang Implementasi Jaminan Fidusia Implementasi Jaminan Fidusia Dalam Pemberian Kredit Dalam Pemberian Kredit Di Indonesia, Badan Pembinaan Hukum Nasional Departemen Hukum dan Hak Asasi Manusia, Jakarta, 2006, hlm. 35.

${ }^{7}$ Gunawan Widjaja dan Ahmad Yani, Jaminan Fidusia. Jakarta: RajaGrafindo Persada, Jakarta, 2000, hm. 111 dan 113.

${ }^{8}$ Sudjana, "Hak Cipta sebagai Jaminan Kebendaan Bergerak Dikaitkan dengan Pengembangan Obyek Jaminan Fidusia", Jurnal Mimbar Hukum, Volume 24, Nomor 3, Oktober, 2012, hlm. 409.

${ }^{9}$ Munir Fuady, Jaminan Fidusia, Citra Aditya Bakti, Bandung, 2000, hlm. 3.

${ }_{10}$ Marulak Pardede (Ketua Tim), Loc. Cit.
} 
lain. Sebagai kata sifat, istilah fidusia menunjukkan pengertian tentang hal yang berhubungan dengan kepercayaan (trust). ${ }^{11}$

Dari rumusan pengertian fidusia dalam UU No. 42/1999 dapat diketahui bahwa pengalihan hak milik atas suatu barang bergerak yang dijaminkan hanya sebatas secara kepercayaan saja. Pengalihan secara kepercayaan merupakan perbuatan abstrak yang dilandasi oleh alam pemikiran barat, seolah-olah barang itu sebagai milik kreditor selama perjanjian utang piutang belum berakhir. Sedangkan sesuai dengan fidusia sebagai jaminan hutang kepemilikan barang jaminan secara nyata (konkrit) masih tetap berada di tangan debitor. Hanya saja, dengan cara yang demikian debitor telah siap sedia jika tidak dapat membayar hutangnya, sehingga ia wajib menyerahkan barang tersebut kepada kreditor untuk dijual lelang. ${ }^{12}$

Di dalam jaminan fidusia terjadi pengalihan hak kepemilikan atas benda objek jaminan. Pengalihan itu terjadi atas dasar kepercayaan dengan janji benda yang hak kepemilikannya dialihkan tetap dalam penguasaan pemilik benda. Pengalihan hak kepemilikan itu dilakukan dengan cara constitutum possesorium (verklaring van houderschap). Ini berarti pengalihan hak kepemilikan atas suatu benda dengan melanjutkan penguasaan atas benda tersebut dimaksud untuk kepentingan penerima fidusia. ${ }^{13}$ Pengalihan hak kepemilikan tersebut dengan melanjutkan penguasaan atas benda tersebut untuk kepentingan penerima fidusia. Secara fisik benda tersebut tetap dikuasai oleh pemberi fidusia, namun hak yuridisnya saja yang diserahkan atas benda tersebut, pemberi fidusia tetap mempunyai hak pemanfaatan. ${ }^{14}$

Pranata jaminan fidusia telah dikenal dan diberlakukan dalam masyarakat hukum Romawi. Ada dua bentuk jaminan fidusia, yaitu: jaminan fidusia cum creditore dan fidusia cum amico, yang timbul dari perjanjian yang disebut pactum fiduciae, kemudian diikuti dengan penyerahan hak (in iure cession). Fiducia cum

\footnotetext{
${ }^{11}$ Tan Kamelo, Hukum Jaminan Fidusia: Suatu Kebutuban Yang Didambakan, Alumni, Bandung, 2004, hlm. 40 .

12 Gatot Supramono, Perbankan dan Masalah Kredit: Suatu Tinjauan di Bidang Yuridis, Rineka Cipta, Jakarta, 2009, hlm. 235.

${ }^{13}$ Gunawan Widjaja dan Ahmad Yani, Op. Cit., hlm. 129.

${ }^{14}$ Elis Herlina dan Sri Santi, "Perlindungan Hukum Terhadap Konsumen Pada Perjanjian Pembiayaan dengan Fidusia Tidak Terdaftar”, Jurnal Ius Quia Iustum, Volume 25, Issue 2, Mei 2018, hlm. 283.
} 
creditore contracta, artinya janji kepercayaan yang dibuat dengan kreditor, dikatakan debitor akan mengalihkan kepemilikan atas suatu benda kepada kreditor sebagai jaminan atas hutangnya dengan kesepakatan kreditor akan mengalihkan kembali kepemilikan tersebut kepada debitor apabila hutangnya sudah dibayar lunas. Kalau dihubungkan dengan sifat yang ada pada setiap pemegang hak, maka dikatakan debitor mempercayakan kewenangan atas suatu barang kepada kreditor untuk kepentingan kreditor sendiri (sebagai jaminan pemenuhan perikatan oleh kreditor). ${ }^{15}$

Timbulnya fiducia cum creditore disebabkan kebutuhan masyarakat akan hukum jaminan. Waktu itu dirasakan adanya suatu kebutuhan akan adanya hukum jaminan ini yang belum diatur oleh konstruksi hukum. Dengan fiducia cum creditore, kewenangan yang dimiliki kreditor akan lebih besar, yaitu sebagai pemilik atas barang jaminan. Debitor percaya kreditor tidak akan menyalahgunakan wewenang yang diberikan itu. Kekuatannya hanya terbatas pada kepercayaan dan secara moral saja dan bukan kekuatan hukum. Debitor tidak akan berbuat apa-apa jika kreditor tidak mau mengembalikan hak milik atas barang jaminan itu. Hal ini merupakan kelemahan fidusia pada bentuk awalnya jika dibandingkan dengan sistem hukum jaminan yang kita kenal sekarang. Karena adanya kelemahan itu, ketika gadai dan hipotik berkembang sebagai hak-hak jaminan, fidusia menjadi terdesak dan bahkan akhirnya hilang sama sekali dari hukum Romawi. Jadi fidusia timbul karena memang ada kebutuhan masyarakat akan hukum jaminan dan kemudian lenyap karena dianggap tidak lagi dapat memenuhi kebutuhan tersebut. ${ }^{16}$

Masyarakat Romawi pada waktu itu menganggap gadai dan hipotik lebih sesuai, karena adanya aturan tertulis, sehingga lebih memberikan kepastian hukum. Gadai dan hipotik juga memberikan hak-hak yang seimbang antara kreditor dan debitor. Demikian pula hak-hak dari pihak ketiga akan lebih terjamin kepastiannya, karena ada aturannya pula. Masyarakat Romawi juga mengenal satu pranata lain di samping pranata jaminan fidusia di atas, yaitu pranata titipan yang disebut fiducia cum amino contracta, artinya janji kepercayaan yang dibuat dengan teman.

\footnotetext{
15 Marulak Pardede (Ketua Tim), Op. Cit., hlm. 21.

${ }^{16}$ Ibid., hlm. 21-22.
} 
Pranata fiducia cum amino contracta pada dasarnya sama dengan pranata "trust" sebagaimana dikenal dalam sistem hukum common law. Lembaga ini sering digunakan dalam hal seorang pemilik suatu benda harus mengadakan perjalanan ke luar kota dan sehubungan dengan itu menitipkan kepemilikan benda tersebut kepada temannya dengan janji bahwa teman tersebut akan mengembalikan kepemilikan benda tersebut jika pemiliknya sudah kembali dari perjalanannya. Di dalam fiducia cum amino contracta ini kewenangan diserahkan kepada pihak penerima, akan tetapi kepentingan tetap ada pada pihak pemberi. ${ }^{17}$

Sejak zaman Romawi sudah dikenal lembaga fidusia, waktu itu dibedakan ada 2 pranata, yaitu: "fiducia cum creditore contracta" dan "fiducia cum amico contracta". Perbedaannya, kalau pranata "fiducia cum creditore contracta" merupakan lembaga jaminan hutang, sedangkan pranata "fiducia cum amico contracta" merupakan lembaga penitipan harta kekayaan. Pranata "fiducia cum creditore contracta" mengandung janji kreditor akan mengembalikan hak milik harta kekayaan yang diserahkan kepadanya kepada debitor lagi manakala hutang telah dilunas. Dibedakan dengan gadai, pada "fiducia cum creditore contracta" benda jaminannya secara fisik tetap berada dalam penguasaan debitor. Berlainan dengan pranata "fiducia cum amico contracta", mengandung janji seseorang (amico) akan mengembalikan harta kekayaan yang telah dititipkan padanya oleh seseorang (pater familias). Di dalam fiducia cum amico contracta, seseorang menerima sesuatu barang yang diserahkan oleh seorang yang lain sebagai titipan untuk disimpan dan diurus, kemudian dikembalikan lagi.

Sejarah Romawi sesuai perkembangan, kemudian mengenal lembaga gadai dan hipotik, sehingga mengakibatkan baik fiducia cum creditore maupun fiducia cum amico, menjadi terdesak dan akhirnya tenggelam. Tiba saatnya ketika bangsabangsa Eropa Kontinental mengadopsi hukum Romawi, lembaga fidusia sudah tidak terdeteksi lagi. Justru gadai dan hipotik yang diambil, lalu dikembangkan sesuai tuntutan kebutuhan. Kondisi ini juga dialami oleh pembentuk BW, sehingga gadai dan hipotik saja yang diatur sesuai sistematika penetapan

${ }^{17}$ Ibid., hlm. 22. 
penggolongan benda, sedangkan fidusia karena sudah hilang dari peredaran, tentu saja tidak terdeteksi lagi untuk diangkat dalam kodifikasi. ${ }^{18}$

\section{Esensialitas Pengalihan Hak Kepemilikan Benda Objek Jaminan Fidusia}

Menurut UU No. 42/1999, fidusia adalah "pengalihan hak kepemilikan suatu benda atas dasar kepercayaan", artinya fidusia dimaknai sebagai "pengalihan hak kepemilikan". Mengandung arti bahwa dalam fidusia terjadi "pengalihan" hak kepemilikan atas suatu benda dari debitor kepada kreditor, dengan janji hak kepemilikan atas suatu benda yang dialihkan itu akan dikembalikan pada waktu utang debitor dinyatakan lunas. Di sini terjadi pemindahan hak kepemilikan benda yang menjadi objek jaminan fidusia. Tidak hanya terjadi penyerahan bendanya saja agar dapat berada dalam kekuasaan kreditor, melainkan hak kepemilikan atas bendanya juga ikut dialihkan kepada kreditor. Hal ini bisa saja dimaknai bahwa kreditor penerima fidusia akan menjadi pemilik dari benda yang menjadi objek jaminan fidusia tersebut selama perjanjian fidusia berlangsung.

Hakikat hak kepemilikan suatu benda dalam konteks hukum jaminan tidak hanya semata-mata hak penguasan atas bendanya saja, melainkan termasuk pula hak milik atas bendanya. Dengan kata lain makna hak kepemilikan atas benda itu meliputi "hak milik atas benda dan hak penguasaan atas benda". ${ }^{19}$ Jika debitor melakukan pengalihan hak kepemilikan atas suatu benda yang menjadi objek jaminan fidusia, maka kekuasaan debitor menjadi berkurang, karena sebagian kekuasaan atas benda yang menjadi objek jaminan fidusia telah dialihkan kepada kreditor. Oleh karena itu di dalam fidusia tidak hanya hak penguasaan atas benda yang menjadi objek jaminan fidusia yang dialihkan kepada kreditor, melainkan juga hak kepemilikan atas benda.

Secara yuridis memang terdapat perbedaan antara pengalihan dan penyerahan, sebab pengalihan hak milik bermaksud memindahkan hak milik, sedangkan penyerahan hak milik dapat berupa penyerahan hak milik untuk dijadikan jaminan, atau penyerahan hak milik untuk kenikmatan (pinjam pakai, sewa menyewa, penitipan), dan penyerahan hak milik yang hak miliknya beralih

${ }^{18}$ Moch. Isnaeni, Op. Cit., hlm. 64.

19 Tan Kamelo, Op. Cit., hlm. 190. 
dengan sesungguhnya seperti jual beli. ${ }^{20}$ Jika mencermati lembaga jaminan kebendaan gadai dan hipotik dalam BW, amat dipahami adanya prinsip selama benda dijadikan objek jaminan, hak milik benda yang bersangkutan, diakui tetap ada pada pihak debitor. Atas "agunan" yang bersangkutan, kreditor hanya sekedar mempunyai hak jaminan kebendaan dan bukan hak kepemilikan. Bahkan diperjanjikan sedari awal membuat perjanjian jaminan, sekalipun dengan wanprestasinya debitor disepakati agunan otomatis menjadi milik kreditor adalah dilarang.

Hal di atas penting dalam rangka untuk memberikan pelindungan hukum kepada debitor yang punya posisi relatif lemah, saat mengajukan permohonan hutang kepada kreditor. Bermula karena itu, di dalam ketentuan gadai dihadirkan Pasal 1154 BW dan hipotik diatur dalam Pasal 1178 BW. Hal tersebut tidak lain sebagai upaya untuk memberikan pelindungan hukum eksternal kepada pihak yang lemah, yaitu pihak debitor yang terdesak dan dihimpit kebutuhan dana pinjaman. Kedua pasal BW tersebut, sekaligus berperan sebagai belenggu bagi kekuatan kreditor yang relatif besar dalam menguasai kehendak debitor, agar supaya tak dimanfaatkan demi mendapatkan keurungan besar secara tidak senonoh. Pasal 1154 juncto Pasal 1178 BW bagai burung besi bersayap ganda, dimana satu sayap untuk memberikan pelindungan hukum eksternal kepada debitor, sedangkan sayap lainnya berperan sebagai belenggu kekuasaan besar kreditor agar tak disalahgunakan. ${ }^{21}$

Kendati hak kepemilikan benda yang menjadi objek jaminan fidusia tersebut telah dialihkan kepada penerima fidusia, namun bendanya tetap dalam penguasaan pemilik benda, sehingga tidak tertutup kemungkinan bisa dipindahtangankan oleh pemberi fidusia kepada pihak ketiga. Saat hendak dieksekusi ketika pemberi fidusia dianggap wanprestasi, adakalanya benda yang menjadi jaminan fidusia tidak ada, bahkan adakalanya bersamaan dengan pemberi fidusia tidak ada lagi. Keadaan demikian menunjukkan kreditor penerima fidusia mempunyai posisi yang lemah jika berhadapan dengan debitor pemberi fidusia.

\footnotetext{
${ }^{20}$ Nurfaidah Said, Op. Cit., hlm. 27.

${ }^{21}$ Moc. Isnaeni, Op. Cit., hlm. 95-96.
} 
Berbeda dengan perjanjian jaminan pada umumnya, perjanjian fidusia mengonstruksikan diri pada adanya "pengalihan hak kepemilikan" suatu benda atas dasar kepercayaan seperti halnya akibat hukum pada fiducia cum creditore. Konstruksi hukum demikian cukup beralasan berkaitan dengan asas bezit atas benda bergerak yang merupakan titel sempurna (bezit geld als volkomend titel). Hal tersebut sebagai upaya melindungi pihak yang memberikan pinjaman direkonstrusikan berpindahnya hak milik atas benda yang menjadi objek jaminan fidusia dari debitor kepada kreditor yang seolah-olah sebagai pemilik benda itu. Berhubung penguasaan benda yang hak miliknya dialihkan tersebut tetap berada dalam penguasaan debitor selaku pemilik benda asal.

Kreditor dalam perjanjian fidusia yang di atas seolah-olah menerima pengalihan suatu hak kepemilikan atas benda dari debitor, walaupun pengalihannya di sini hanya atas dasar "kepercayaan". Jadi, pada perjanjian fidusia dikontruksikan bahwa pemberi fidusia mengalihkan secara kepercayaan suatu hak kepemilikan atas bendanya sebagai agunan bagi pelunasan utang tertentu, melalui perjanjian fidusia hak kepemilikan atas benda yang menjadi objek jaminan fidusia telah beralih kepada penerima fidusia. Dengan konstruksi hukum seperti ini, penerima fidusia akan terlindungi, karena pemberi fidusia tidak dapat mengalihkan benda yang menjadi objek jaminan fidusia tersebut. Sebaliknya penerima fidusia mempunyai hak meminjampakaikan benda yang menjadi objek jaminan fidusia itu kepada pemberi fidusia yang berkedudukan sebagai peminjam pakai.

Hal di atas selaras dengan landmark yurisprudensi fidusia bernuansa jual beli seolah-olah, supaya melahirkan hak pinjam pakai bagi penerima fidusia. Bahkan pengalihan hak miliknya pun pada fidusia digambarkan sebagai pengalihan atau penyerahan secara abstrak, yakni penyerahan secara constitutum possessorium. Penyerahan secara constitutum possessorium ialah pengalihan atau penyerahan hak kepemilikan suatu benda oleh debitor kepada kreditor yang bendanya tetap berada dalam penguasaan secara nyata oleh pemberi fidusia.

Mengenai penyerahan dalam BW sering dipakai beberapa istilah, tetapi mempunyai pengertian sama dengan penyerahan, yaitu: opdracht, overdracht, transport acte untuk penyerahan atas benda tak bergerak, cessie untuk penyerahan 
piutang atas nama dan inbreng untuk penyerahan dalam hal warisan. Penyerahan (levering) dalam konsep BW merupakan cara memperoleh hak milik yang paling sering terjadi dalam masyarakat. Hak milik atas suatu benda baru berpindah kepada orang lain setelah adanya penyerahan. ${ }^{22}$ Konsep BW membedakan penyerahan itu atas 2 macam, yaitu: penyerahan secara yuridis (juridische levering) dan penyerahan secara nyata (feitelijke levering).

Perjanjian-perjanjian yang bersifat obligatoir harus ada penyerahan yuridis dan penyerahan nyata. Dalam bahasa Perancis memang ada dua macam istilah, yaitu tradition (juridische levering) dan deliverance (penyerahan nyata). Tergantung pada jenis kebendaannya, bisa bersamaan atau terpisah levering atas suatu benda. Terhadap benda bergerak pada umumnya penyerahan yuridis dan penyerahan secara nyata itu biasanya jatuh bersamaan. Sebaliknya pada benda tak bergerak, kedua macam penyerahan itu berpisah, di mana juridische levering-nya terjadi dengan pendaftaran benda itu dalam daftar umum dan feitelijke levering-nya terjadi dengan penyerahan misalnya kunci dari satu rumah atau pembukaan dari pagarnya. ${ }^{23}$

Awal lahirnya perjanjian fidusia, penyerahan hak milik atas objek fudisia adalah penyerahan hak milik sempurna, karena memang dikonstruksikan sebagai jual beli semu atau jual beli dengan hak membeli kembali. Inilah substansi dari fiducia cum creditore. Sebagai jual beli (semu atau dengan hak membeli kembali), maka penyerahan hak milik pada prinsipnya hanya ada pada suatu hubungan hukum jual beli, tukar menukar atau hibah, tidak dapat terjadi pada perjanjian penjaminan atau pinjam meminjang uang dengan jaminan kebendaan. ${ }^{24} \mathrm{Hal}$ ini sejalan dengan pendapat dari aliran kuno, bahwa hak milik fidusia adalah sempurna, berdasarkan perjanjian fidusia itu merupakan perjanjian obligatoir.

Pendapat di atas dianut sejak zaman Romawi dan disebut fiducia cum creditore seperti yang diikuti antara lain oleh Jarolimek dalam bukunya Eigendom tot zekerheid. Namun A. Veenhoven dalam bukunya Eigendomsoverdracht menerima pendapat tersebut dengan catatan bahwa hak milik di sini bersifat

\footnotetext{
22 Sri Soedewi Masjchoen Sofwan, Hukum Perdata: Hukum Benda, Liberty, Yogyakarta, 1981, hlm. 67-68.

${ }^{23}$ Ibid., hlm. 75-76.

${ }^{24}$ Nurfaidah Said, Op. Cit., hlm. 29.
} 
sempurna yang terbatas, karena digantungkan pada syarat tertentu. Hak milik pemilik fidusia digantungkan pada syarat putus (ontbindende voorwaarde). Hak milik pemilik fidusia yang sempurna baru lahir jika pemberi fidusia wanprestasi. Bagi pemberi fidusia, hak miliknya yang sempurna digantungkan pada syarat tangguh (opschortende voorwaarde). Jika pemberi fidusia memenuhi kewajibannya melunasi hutang, demi hukum benda fidusia kembali menjadi hak miliknya. ${ }^{25}$

Pendapat aliran kuno tersebut sesuai dengan teori kemilikan (title theory). Menurut teori ini, dalam perjanjian jaminan fidusia, kreditor adalah sebagai pemilik yang sempurna dari benda yang dijaminkan. Berdasarkan teori ini, perjanjian jaminan fidusia memiliki karakter perorangan. Teori ini merupakan awal dari perkembangan jaminan fidusia yang masih bersifat konvensional dan kurang dapat menjawab persoalan hukum jaminan fidusia secara memuaskan. ${ }^{26}$

Sementara itu menurut pendirian yang modern seperti yang dikemukakan oleh Pitlo dalam bukunya zakenrecht dan Kleyn dalam tulisannya "Pengakuan atas milik fidusiyer sebagai jaminan", memandang perjanjian penyerahan hak milik secara fidusia sebagai jaminan, merupakan hak milik terbatas. Perjanjian ini hanya melahirkan hak jaminan dan bukan hak milik. Perbedaan kedua pendapat ini akan menjadi jelas dalam hal pemilik fidusia jatuh pailit. Menurut pendapat pertama, jika pemilik fidusia jatuh pailit seluruh harta kekayaan pemilik fidusia, termasuk benda fidusia, jatuh ke dalam boedel pailit. Kurator kepailitan dapat menuntut benda fidusia yang berada didalam kekuasaan pemberi fidusia, untuk dijual sebagai pembayar hutang pemberi fidusia. Hak milik pemberi fidusia terhadap benda fidusia hanya bersifat pribadi (persoonlijk).

Menurut Aser - Van oven yang mewakili pendapat modern, jika pemilik fidusia pailit, benda fidusia tidak termasuk kedalam boedel pailit. Kurator kepailitan tidak berhak menuntut benda fidusia dari kekuasaan pemberi fidusia. Benda fidusia hanya dapat dilelang dalam batas-batas sebagai benda jaminan untuk melunasi hutang pemberi fidusia. ${ }^{27}$ Pendapat aliran modern ini sejalan dengan teori jaminan (liens theory) yang menyatakan, bahwa perjanjian jaminan

25 Mariam Darus Badrulzaman, Bab-bab tentang Credietverband, Gadai, dan Fiducia, Citra Aditya Bakti, Bandung, 1991, hlm. 96-97.

${ }^{26}$ Tan Kamelo, Op. Cit., hlm. 192.

${ }^{27}$ Mariam Darus Badrulzaman, Op. Cit., hlm. 97. 
fidusia merupakan analogi dari gadai dan memiliki karakter kebendaan. Kreditor penerima jaminan fidusia hanya sebagai pemilik yang terbatas dalam arti sebagai pemilik jaminan. ${ }^{28}$

Apabila dibandingkan dengan gadai, dalam jaminan fidusia sebagai agunan diperlukan jaring pengaman untuk melindungi kepentingan kreditor penerima fidusia berkaitan dengan kemudahan dalam mengakses benda yang menjadi objek jaminan fidusia. Hal ini dikarenakan keberadaan benda jaminannya tetap dalam penguasaan pemilik benda. Untuk itu pembebanan jaminan fidusia dikonstruksikan didahului dengan pengalihan hak kepemilikan atas benda jaminannya dari debitor pemberi fidusia kepada kreditor penerima fidusia. Kreditor penerima fidusia kemudian dapat memiliki kewenangan untuk menjual benda yang menjadi objek jaminan fidusia selayaknya sebagai pemilik benda manakala debitor pemberi fidusia wanprestasi.

Disisi lain, konstruksi hukum yang demikian dimaksudkan untuk membatasi kewenangan debitor pemberi fidusia selaku pemilik benda setelah benda yang menjadi objek jaminan fidusia itu dibebani dengan jaminan fidusia. Oleh karenanya dirumuskan kalau hak kepemilikan atas benda yang menjadi objek jaminan telah beralih kepada kreditor penerima fidusia. Di dalam perjanjian fidusia ini yang dialihkan hanyalah hak milik atas benda yang menjadi objek jaminan fidusia oleh debitor pemberi fidusia kepada kreditor penerima fidusia, sementara penguasaan secara nyata atas benda yang menjadi objek jaminan fidusia tersebut tetap berada di tangan debitor pemberi fidusia, makanya oleh para ahli dikatakan penyerahan kebendaan jaminan fidusia dilakukan secara constitutum possessorium.

Bila batasan fidusia dicermati lebih lanjut, tampak jelas UU No. 42/1999 mengonstruksikan adanya pemisahan antara penyerahan yuridis dan penyerahan nyata. Penyerahan yuridis ditandai dengan frasa "pengalihan hak kepemilikan suatu benda atas dasar kepercayaan", sedangkan penyerahan nyata ditandai dengan frasa "benda yang hak kepemilikannya dialihkan tersebut tetap dalam penguasaan pemilik benda". Pengalihan di sini dalam rangka dijadikan agunan

28 Tan Kamelo, Loc. Cit. 
pelunasan hutang, tetapi untuk selama debitor pemberi fidusia tidak wanprestasi, penyerahan nyata atas benda yang menjadi objek jaminan fidusia belum dilakukan. Dengan pemisahan penyerahan hak kepemilikan atas benda yang menjadi objek jaminan fidusia tersebut, maka tercipta pengalihan hak milik benda fidusia secara pura-pura atau semu kepada kreditor penerima fidusia.

Penggunaan konsep splitsing dari kedua unsur levering, bahwasanya penyerahan hak milik benda jaminan fidusia yang dimaksud, bukan benar-benar dalam pengertian levering sesungguhnya sebagaimana dimaksud dalam Pasal 612 BW. Bahkan bukan pula termasuk model penyerahan secara constitutum possessorium seperti yang disebut oleh banyak orang. Sebaliknya penyerahan tersebut bertolak dari konsep, bahwa sebatas pada penyerahan yuridis belaka, tanpa seketika diikuti oleh penyerahan nyata. Berlandas pada konsep ini, maka hak milik benda objek fidusia tidak sungguh-sungguh beralih, sehingga debitor yang tetap menguasai agunan, dan sesungguhnya masih berposisi selaku pemilik yang tak sepenuhnya sempurna, karena debitor belum melakukan penyerahan nyata, akibat masih dikuasainya objek jaminan. Ketidaksempurnaan kepemilikan benda objek fidusia, tujuannya agar nanti di belakang hari saat debitor wanprestasi, sesegera mungkin fietelijke levering dilaksanakan oleh debitor. ${ }^{29}$

Melalui penyerahan secara yuridis terjadilah penjaminan secara fidusia, yang mengakibatkan hak milik agunan menjadi berpindah berdasar kepercayaan, dari tangan debitor kepada kreditor. Namun perpindahan hak milik objek jaminan fidusia tersebut, karena didasarkan pada unsur "kepercayaan", proses penyerahan belum dilakukan secara penuh. Hanya penyerahan yuridisnya yang terjadi, sedangkan penyerahan nyatanya, masih dipersyaratkan atau digantungkan pada suatu peristiwa tertentu di kemudian hari yang lebih ditentukan oleh sikap debitor atas hutang yang sudah diunduhnya. Apabila sikap debitor tidak membayar hutangnya, maka feitelijke levering wajib dilaksanakan oleh debitor. Sebaliknya kalau debitor menunjukkan sikap positif, membayar kembali pinjamannya sesuai kesepakatan, justru kreditor akan melakukan juridische levering sebagai tanda kepercayaan, mengembalikan lagi kepada debitor,

${ }^{29}$ Moch. Isnaeni, Op. Cit., hlm. 98. 
sehingga hak milik debitor atas benda fidusia balik utuh sedia kala sesuai dengan sifat ikutan dari jaminan fidusia. ${ }^{30}$

Hal tersebut sesuai dengan arti kata "kepercayaan" yang menjadi dasar penyerahan hak milik benda jaminan fidusia. Hubungan hukum antara pemberi fidusia (debitor) dan penerima fidusia (kreditor) merupakan hubungan hukum yang berdasarkan kepercayaan. Pemberi fidusia percaya bahwa penerima fidusia mau mengembalikan hak milik benda jaminan fidusia yang telah diserahkan setelah dilunasi utangnya. Sebaliknya penerima fidusia percaya bahwa pemberi fidusia tidak akan menyalahgunakan benda jaminan fidusia yang berada dalam kekuasaannya. ${ }^{31}$

Jika memerhatikan UU No. 42/1999, maka sesungguhnya yang dialihkan itu baru hak milik benda jaminan fidusia secara yuridis, sedangkan beralihnya secara nyata atas benda jaminan fidusia masih digantungkan pada suatu peristiwa tertentu bilamana debitornya wanprestasi. Sebaliknya manakala debitor tidak wanprestasi, benda jaminan fidusia akan dikembalikan secara utuh oleh kreditor penerima fidusia. Mengingat penyerahan hak milik benda jaminan fidusia belum utuh atau sempurna, maka dibuatkan akta peralihan secara yuridis atas benda jaminan fidusia yang dituangkan akta notaris, yang dinamakan dengan akta jaminan fidusia. Hal ini dalam rangka melindungi kepentingan kreditor penerima fidusia seandainya debitor penerima fidusia wanprestasi, yang dengan sendirinya kreditor penerima fidusia mempunyai kewenangan untuk menjual benda objek jaminan fidusia melalui pelelangan umum atau secara di bawah tangan.

Berhubung penyerahan hak milik dalam fidusia tidak dilakukan secara nyata, maka dipersyaratkan pembebanannya menggunakan akta notaris. Hal tersebut untuk melindungi kepentingan kreditor agar tetap bisa melakukan eksekusi pada saat debitor meninggal dunia sebelum kreditor melaksanakan pelunasan melalui objek jaminan. Adanya persyaratan pembebanan dengan akta notaris dan pendaftaran jaminan fidusia, maka kreditor dapat mempertahankan hak kebendaan itu kepada siapapun dan dalam kondisi apapun.

${ }^{30}$ Ibid., hlm. 105-106.

31 Zaeni Asyhadie dan Rahma Kusumawati, Hukum Jaminan Di Indonesia: Kajian Berdasarkan Hukum Nasional dan Prinsip Ekonomi Syariah, RajaGrafindo Persada, Jakarta, 2018, hlm. 156. 
Kemunculan penyerahan secara constitutum possessoirum dalam jaminan fidusia dilatarbelakangi adanya kebutuhan dalam praktik. Hal ini ketika seorang debitor yang mengadakan hubungan hutang piutang dengan jaminan barang yang diperlukan oleh si debitor untuk mencari nafkah sehingga jika barang tersebut diserahkan secara nyata kepada kreditor sebagaimana yang terjadi dalam gadai, maka kelangsungan hidup debitor dapat terganggu. Penyerahan secara constitutum possessorium kemudian timbul sebagai solusi penguasaan atas benda jaminan fidusia tetap berada di tangan debitor. ${ }^{32}$

Jika dilihat dari sejarah kelahiran fidusia, penyerahan hak milik secara kepercayaan dimaknai sebagai pengalihan hak milik atas benda jaminan fidusia dari debitor kepada kreditor seperti halnya dalam perjanjian jual beli dengan hak kembali. Hak milik atas benda jaminan fidusia telah beralih kepada kreditor penerima fidusia, sehingga yang bersangkutan berkedudukan sebagai pemilik sempurna atas benda jaminan fidusia. Konsep fidusia sebagaimana dirumuskan dalam Pasal 1 angka 1 UU No. 42/1999, bahwa pengalihan hak kepemilikan suatu benda atas dasar kepercayaan tidak dimaknai sebagai pemindahan hak milik atas benda layaknya seperti perjanjian jual beli, melainkan pemindahan hak milik benda jaminan fidusia secara pura-pura.

Hak milik atas benda jaminan fidusia tersebut sebagian telah beralih dari debitor pemberi jaminan fidusia kepada kreditor penerima fidusia. Hak kepemilikan atas suatu benda jaminan fidusia oleh debitor tidak utuh lagi, karena pemindahan hak milik benda jaminan fidusia itu hanya secara yuridis saja sebagaimana dituangkan dalam akta jaminan fidusia, belum diikuti dengan feitelijk levering atas hak milik benda jaminan fidusia, karena digantungkan pada syarat tertentu yang mungkin akan terjadi.

Adanya juridische levering ini mengakibatkan debitor yang mempunyai hak milik agunan tetapi tidak sempurna lagi, menjadikan dirinya tidak lagi punya kewenangan untuk menjaminkan ulang objek jaminan fidusia. Sebab sesuai adagium dalam hukum jaminan, bahwa yang wenang menjaminkan sebuah benda adalah pemilik, dalam pengertian kepemilikan benda yang bersangkutan benar-

32 D.Y. Witanto, Hukum Jaminan Fidusia dalam Perjanjian Pembiayaan Konsumen (Aspek Perikatan, Pendaftaran, dan Eksekusi), Mandar Maju, Bandung, 2015, hlm. 172-173. 
benar dalam keadaan utuh. Sedang kepemilikan objek fidusia dari debitor tidak utuh lagi, sehingga layak kalau debitor menjadi tidak wenang menjaminkan ulang fidusia. ${ }^{33}$

Kendaraan bermotor pada umumnya dijadikan objek jaminan fidusia. Pada umumnya dapat dipastikan bahwa pengalihan hak kepemilikan atas benda jaminan fidusia sebenarnya tidak pernah dilaksanakan secara konkrit. Saat kendaraan bermotor dibebani jaminan fidusia, secara nyata tidak pernah ada perpindahan hak agunan dari tangan debitor kepada kreditor. Ini dapat dideteksi, bahwa dokumen kendaraan bermotor yang ditahan kreditor, secara konkrit tidak pernah dilakukan balik nama untuk mengikuti seruan Pasal 1 angka 1 UU No. 42/1999, bahwa hak milik agunan dipindahkan dari debitor kepada kreditor.

Sebagai benteng pengaman, memang dibangun suatu kesepakatan bahwa debitor memberikan kuasa kepada kreditor, sewaktu-waktu yang dianggap perlu untuk melakukan balik nama agunan. Hal inipun dalam praktik tidak selamanya dilakukan bila ada saatnya debitor wanprestasi, untuk kemudian dilangsungkan penjualan lelang objek jaminan fidusia. Hal ini terjadi dengan dilatarbelakangi sikap kreditor yang berlindung pada klausula "kuasa menjual" atau melaksanakan penjualan agunan di hadapan umum dengan dasar sertifikat jaminan fidusia. ${ }^{34}$

Sejatinya maksud pengalihan kepemilikan dalam jaminan fidusia itu bukan dalam arti pengalihan "kepemilikan" yang sebenarnya, sebagaimana makna "levering" dalam Pasal 584 BW. Hal yang perlu dicermati dan dilihat adalah maksud para pihak bahwa benda tersebut dijadikan sebagai objek jaminan, bukan bermaksud untuk mengalihkan benda dalam rangka perjanjian jual beli. Makna pengalihan hak kepemilikan atas benda jaminan fidusia tersebut bukan bermaksud untuk mengalihkan kepemilikan dalam arti sebenarnya, akan tetapi bermaksud untuk menjamin benda tersebut atas hutang yang telah diterimanya. ${ }^{35}$

Bagi kreditor penerima fidusia, pengalihan hak kepemilikan benda jaminan fidusia itu menimbulkan akibat hukum mempunyai wenang bagaikan sebagai

${ }^{33}$ Moch. Isnaeni, Op. Cit., hlm. 118

${ }^{34}$ Ibid., hlm. 118-119.

35 Trisadini Prasastinah Usanti dan Leonora Bakarbessy, Buku Referensi Hukum Perbankan, Hukum Jaminan, Revka Petra Media, Surabaya, 2013, hlm. 88-89. 
seorang pemilik benda, namun tidak dimaksudkan untuk memiliki benda yang menjadi objek jaminan fidusia. Dengan kata lain pengalihan hak kepemilikan benda jaminan fidusia dalam pembebanan jaminan fidusia dimaksudkan untuk melahirkan hak-hak yang seyogianya dimiliki oleh seorang pemilik benda. Kreditor penerima fidusia seolah-olah berkedudukan sebagai pemilik benda agar dapat melahirkan hak kepemilikan untuk menjual benda yang menjadi objek jaminan fidusia.

Hak kepemilikanpun baru tercipta pada saat debitor pemberi fidusia dinyatakan wanprestasi. Pengalihan hak kepemilikan atas benda jaminan fidusia dimaknai dalam rangka memberikan wewenang kepada kreditor penerima fidusia. Penerima fidusia kemudian menjadi layaknya seorang pemilik benda yang mempunyai wewenang menjual benda yang menjadi objek jaminan fidusia. Pengalihan hak kepemilikan ini tentunya tidak dimaksudkan agar benda yang menjadi objek jaminan fidusia itu dimiliki kreditor penerima fidusia.

Konsep fidusia saat ini yang berfungsi sebagai jaminan bukan pengalihan kepemilikan sebagaimana yang terjadi pada zaman Romawi. Hal ini terlihat jelas dalam ketentuan Pasal 33 UU No. 42/1999. Ketentuan tersebut melarang penerima fidusia untuk memiliki benda yang menjadi objek jaminan fidusia apabila debitor cidera janji atau wanprestasi. Setiap janji yang memberikan kewenangan yang demikian maka menjadi batal demi hukum. Dengan demikian, tidak terjadi peralihan kepemilikan secara sempurna, akan tetapi yang muncul adalah hak jaminan atas benda yang dijadikan jaminan fidusia. ${ }^{36}$

Pembebanan jaminan fidusia tidak menimbulkan hak sepenuhnya bagi penerima fidusia, karena kreditor tidak menguasai bendanya, tidak berwenang untuk menikmati bendanya, hanya mempunyai kewenangan terhadap benda tersebut sesuai dengan tujuan yang telah diperjanjikan, yaitu sebagai jaminan. ${ }^{37}$ Kendatipun debitor pemberi fidusia wanprestasi, kreditor penerima fidusia dilarang untuk menikmati atau memiliki benda jaminan fidusia tersebut. Kreditor

${ }^{36}$ Badan Pembinaan Hukum Nasional Kementerian Hukum dan Hak Asasi Manusia, Naskah Akademik Rancangan Undang-Undang tentang Perubahan Atas Undang-Undang Nomor 42 Tabun 1999 tentang Jaminan Fidusia, Badan Pembinaan Hukum Nasional Kementerian Hukum dan Hak Asasi Manusia, Jakarta, 2018, hlm. 12.

${ }^{37}$ Rindia Fanny Kusumaningtyas, "Perkembangan Hukum Jaminan Fidusia Berkaitan dengan Hak Cipta sebagai Objek Jaminan Fidusia”, Jurnal Pandecta, Volume 11 Nomor 1, Juni 2016, hlm. 100. 
penerima fidusia hanya berhak untuk menjual benda jaminan tersebut seolaholah ia sebagai pemilik dari benda jaminan fidusia tersebut. ${ }^{38}$

Esensialitas pengalihan kepemilikan atas benda yang menjadi objek jaminan fidusia sebagaimana dimaksud dalam Pasal 1 angka 1 UU No. 42/1999 oleh karenanya tidak dalam rangka pengalihan hak milik atas benda sebagaimana yang terjadi pada perjanjian jual beli. Pengalihan kepemilikan atas benda yang menjadi objek jaminan fidusia tersebut dimaksudkan dalam rangka memberikan hak menjual benda yang menjadi objek jaminan fidusia layaknya sebagai seorang pemilik benda yang mempunyai kewenangan hukum untuk menjual benda objek jaminan fidusia. Hal ini sesuai dengan fungsi jaminan fidusia sebagai agunan bagi pelunasan hutang tertentu yang mengutamakan kedudukan kreditor penerima fidusia terhadap kreditor lainnya.

\section{Penutup}

Berdasarkan analisis di atas, maka penelitian ini menyimpulkan bahwa sebelum lahirnya UU No. 42/1999, fidusia pada hakikatnya diartikan sebagai penyerahan hak milik atas dasar kepercayaan, yang mengandung makna sebagai pemindahan hak milik atas benda objek jaminan fidusia dari debitor pemberi fidusia kepada kreditor penerima fidusia secara sempurna seperti halnya dalam perjanjian jual beli. Hak milik atas benda objek jaminan fidusia itu telah "beralih penuh" kepada kreditor penerima fidusia, sehingga yang bersangkutan berkedudukan sebagai pemilik sempurna atas benda objek jaminan fidusia tersebut. Hal ini selaras dengan konsep fidusia pada zaman Romawi yang berfungsi sebagai pengalihan kepemilikan.

Namun demikian, berdasarkan UU No. 42/1999, makna pengalihan hak kepemilikan atas benda objek jaminan fidusia tidak dalam arti pemindahan hak milik atas suatu benda secara sempurna, melainkan sebatas juridische levering saja, karena dalam pembebanan fidusia masih belum diikuti dengan feitelijke levering, yang bisa terjadi kemudian. Pemindahan hak milik atas benda objek jaminan fidusianya pun dilakukan secara abstrak atas "dasar kepercayaan", yang

38 Lidya Mahendra, R.A Retno Murni, dan Putu Gede Arya Sumertayasa, "Perlindungan Hak-Hak Kreditur Dalam Hal Adanya Pengalihan Benda Jaminan oleh Pihak Debitur", Jurnal Acta Comitas, Nomor 2, Tahun 2016, hlm. 271. 
fungsinya sebagai agunan pelunasan hutang debitor pemberi fidusia. Hanya saja, berdasarkan jurisdiche levering ini, kreditor penerima fidusia mempunyai hak jaminan atas benda yang dijadikan jaminan fidusia, sehingga kreditor penerima fidusia berkedudukan menjadi pemilik benda yang tidak sepenuhnya sempurna. Sebab benda objek jaminan fidusianya masih tetap dalam penguasaan debitor pemberi fidusia.

Pengalihan kepemilikan benda objek jaminan dalam pembebanan fidusia dimaksudkan dalam rangka memberikan hak preferensi kepada kreditor penerima fidusia sebagaimana layaknya sebagai seorang pemilik benda (pemilik benda jaminan). Hal ini bersesuaian dengan fungsi jaminan fidusia sebagai agunan pelunasan hutang. Agar tidak menimbulkan batasan yang dapat berujung pada multitafsir terhadap makna pengalihan hak kepemilikan benda objek jaminan fidusia, maka rumusan pengertian fidusia perlu ditafsir ulang atau dihapus dalam perubahan UU No. 42/1999, sehingga lebih mengedepankan pengaturan jaminan fidusia sebagai hak kebendaan yang memberikan jaminan.

\section{Daftar Pustaka}

\section{Buku}

Asyhadie, Zaeni dan Rahma Kusumawati, Hukum Jaminan Di Indonesia: Kajian Berdasarkan Hukum Nasional dan Prinsip Ekonomi Syariah, RajaGrafindo Persada, Jakarta, 2018.

Badan Pembinaan Hukum Nasional Kementerian Hukum dan Hak Asasi Manusia, Naskah Akademik Rancangan Undang-Undang tentang Perubahan Atas Undang-Undang Nomor 42 Tahun 1999 tentang Jaminan Fidusia, Badan Pembinaan Hukum Nasional Kementerian Hukum dan Hak Asasi Manusia, Jakarta, 2018.

Badruzalman, Mariam Darus, Bab-bab tentang Credietverband, Gadai, dan Fiducia, Citra Aditya Bakti, Bandung, 1991.

Fuady, Munir, Jaminan Fidusia, Citra Aditya Bakti, Bandung, 2000.

Hasbullah, Frieda Husni, Hukum Kebendaan Perdata: Hak-hak Yang Memberikan Kenikmatan Jilid 1, Ind-Hill. Co., Jakarta, 2002.

HS, Salim, Pengantar Hukum Perdata Tertulis (BW), Sinar Grafika, Jakarta, 2003.

Isnaeni, Moch., Noktah Ambigu Norma Lembaga Jaminan Fidusia, Revka Petra Media, Surabaya, 2017.

Kamelo, Tan, Hukum Jaminan Fidusia: Suatu Kebutuhan Yang Didambakan, Alumni, Bandung, 2004. 
Pardede, Marulak (Ketua Tim), Laporan Akhir Penelitian Hukum Laporan Akhir Penelitian Hukum Tentang Implementasi Jaminan Fidusia Implementasi Jaminan Fidusia Dalam Pemberian Kredit Dalam Pemberian Kredit Di Indonesia, Badan Pembinaan Hukum Nasional Departemen Hukum dan Hak Asasi Manusia, Jakarta, 2006.

Sofwan, Sri Soedewi Masjchoen, Hukum Perdata: Hukum Benda, Liberty, Yogyakarta, 1981.

Supramono, Gatot, Perbankan dan Masalah Kredit: Suatu Tinjauan di Bidang Yuridis, Rineka Cipta, Jakarta, 2009.

Tiong, Oey Hoey, Fiducia Sebagai Jaminan Unsur-unsur Perikatan, Ghalia Indonesia, Jakarta, 1984.

Usanti, Trisadini Prasastinah dan Leonora Bakarbessy, Buku Referensi Hukum Perbankan, Hukum Jaminan, Revka Petra Media, Surabaya, 2013.

Usman, Rachmadi, Hukum Jaminan Keperdataan, Sinar Grafika, Jakarta, 2016. Hukum Kebendaan, Sinar Grafika, Jakarta, 2011.

Widjaja, Gunawan dan Ahmad Yani, Jaminan Fidusia. Jakarta: RajaGrafindo Persada, Jakarta, 2000.

Witanto, D.Y., Hukum Jaminan Fidusia dalam Perjanjian Pembiayaan Konsumen (Aspek Perikatan, Pendaftaran, dan Eksekusi), Mandar Maju, Bandung, 2015.

\section{Hasil Penelitian/Tugas Akhir}

Said, Nurfaidah, Prinsip Penyerahan Objek Jaminan Atas Dasar Kepercayaan dalam Perjanjian Fidusia. Ringkasan Disertasi, Program Doktor Program Pascasarjana Universitas Airlangga, Surabaya, 2008.

\section{Jurnal}

Herlina, Elis dan Sri Santi, "Perlindungan Hukum Terhadap Konsumen Pada Perjanjian Pembiayaan dengan Fidusia Tidak Terdaftar", dalam Jurnal Ius Quia Iustum, Volume 25, Issue 2, Mei 2018.

Kusumaningtyas, Rindia Fanny, "Perkembangan Hukum Jaminan Fidusia Berkaitan dengan Hak Cipta sebagai Objek Jaminan Fidusia", Jurnal Pandecta, Volume 11 Nomor 1, Juni 2016.

Mahendra, Lidya, R.A Retno Murni, dan Putu Gede Arya Sumertayasa, "Perlindungan Hak-Hak Kreditur Dalam Hal Adanya Pengalihan Benda Jaminan oleh Pihak Debitur", Jurnal ActaComitas, Nomor 2, Tahun 2016.

Putra, Fani Martiawan Kumara, "Karakteristik Pembebanan Jaminan Fidusia pada Benda Persediaan dan Penyelesaian Sengketa Saat Debitor Wanprestasi, Jurnal Perspektif, Volume XXI, Nomor 1, Tahun 2016, Edisi Januari.

Sjafar, Memet Achirius, "Perampasan Obyek Fidusia dan Akibat Hukumnya", Jurnal Notaire, Volume 2 Nomor 3, Oktober 2019. 
Sudjana, Hak Cipta sebagai Jaminan Kebendaan Bergerak Dikaitkan dengan Pengembangan Obyek Jaminan Fidusia", Jurnal Mimbar Hukum, Volume 24, Nomor 3, Oktober, 2012.

\section{Perundang-undangan}

Burgerlijk Wetboek (Staatsblad Tahun 1847 Nomor 23).

Undang-Undang Nomor 42 Tahun 1999 tentang Jaminan Fidusia (Lembaran Negara Republik Indonesia Tahun 1999 Nomor 168, Tambahan Lembaran Negara Republik Indonesia Nomor 3889). 